\section{Historia bez pointy}

Raz. Dwa. Trzy. Plié. Cztery, pięć. Relevé. Karolina, pointy! Raz. Dwa... Przy drążku rząd dziewczyn wygina się i prostuje w rytm muzyki i słów nauczycielki baletu. Karolina niewiele różni się od swoich koleżanek. Ma piękne, smukłe nogi i długie palce u rąk - jak u pianistki. Przykuwa uwagę jej twarz - skupiona, a jednocześnie pusta. Jakby była zamknięta w swoich myślach.

Kiedy ją zobaczyłam po raz pierwszy, miała 15 lat. Wiązała właśnie swoje różowe pointy... Dla mnie pozostaje do dzisiaj tamtą nastoletnią dziewczyną o niepewnym spojrzeniu i zniewalającym uśmiechu. I taką ją właśnie opisuję, mimo że od tamtego czasu minęło już kilka lat. W moich oczach jest ona bohaterką filmu, który w tym kształcie nigdy nie powstał.

Baletu uczy się od siedmiu lat. Ma już za sobą pierwszy występ w poznańskim Teatrze Muzycznym, występ przygotowanym przez Studio baletowe Anny Niedźwiedź. W spektaklu „Tajemnice świata” tańczyła tylko 2 minuty. Ale wszyscy mówili tylko o niej. Jej profesorka, Anna, marzy, żeby Karolina tańczyła w Polskim Teatrze Tańca.

Karolina o tym nie marzy. Jeszcze nie wie, co będzie robić w przyszłości. Bo przyszłość dla Karoliny nie istnieje.

Nie pamiętam już, jak trafiłam na jej trop. Od dawna pasjonował mnie temat „innych światów”, zwłaszcza świata ciszy. Świat ludzi słyszących i niesłyszących to rzeczywiście dwa różne światy. Postanowiłam zrobić o tym film dokumentalny. Chciałam tym filmem poszukać odpowiedzi albo chociaż zadać pytanie, które fascynowało mnie od czasów akademickich. Czy rzeczywiście, jak twierdzi Wittgenstein, „Granice mojego języka są granicami mojego świata”? Jednocześnie chciałam opisać tę cześć Polaków, która funkcjonuje na marginesie naszego społeczeństwa. Rzec by można nie ma w nim prawa głosu. Na ogół traktujemy ich jak obcokrajowców. Ale czy może być inaczej, skoro mówimy innymi językami. I kim właściwie jesteśmy dla nich? Dotarcie do środowiska osób głuchoniemych jest trudne, ponieważ tworzą swego rodzaju getto - albo to my ich w tym getcie zamykamy.

Film miał być zatytułowany Cisza na cały głos. Chciałam nim opowiedzieć trzy zazębiające się ze sobą historie: Karoliny, Ani i Kasi, które razem pracują nad przygotowaniem spektaklu Inny Świat.

Ucieszona, że znalazłam tak niezwykłą historię, wysłałam do Redakcji Filmu Dokumentalnego TVP 2 eksplikację, która jest pierwszym ogniwem łańcucha produkcyjnego. Najpierw, przez kilka miesięcy, czekałam cierpliwie na decyzję ówczesnego redaktora programująco-zamawiającego, nazywanego w środowisku telewizyjnym rpz-em. Od czasu do czasu dzwoniłam, słysząc w słuchawce: „proszę zadzwonić za miesiąc, jeszcze nie podjąłem decyzji”. W reszcie, po prawie roku, pojechałam na Woronicza, by wydobyć ostateczną odpowiedź. Nie wierzyłam własnym uszom. „Nie”. Widocznie ów rpz sam jest głuchy na taki temat - pomyślałam. Dopiero kilka miesięcy później, na festiwalu w Krakowie, dowiedziałam się kulisów tej odmowy. Ale to zupełnie inna historia. A tymczasem do Karoliny ustawiła się kolejka z TVN.

Karolina jest głuchoniema. Taka się już urodziła. Wszyscy w jej rodzinie - rodzice i trójka rodzeństwa - słyszą. Jest, jak to określa jej wychowawca Wiesław Somerfeld, z rocznika '86 - rocznika „czarnobylskiego”. W Ośrodku dla Dzieci Niesłyszących w Poznaniu, gdzie Karolina uczy się i mieszka, jest wiele takich dzieci. Ich rodziny często chętnie „wypychają je” $\mathrm{z}$ domu do internatu. Chcę sprawdzić, czy tak jest też w wypadku Karoliny, która pochodzi z małej wioski niedaleko Konina. Kiedy razem z jej wychowawcą odwiedzam całą rodzinę, rodzice przygotowują odświętny obiad. Znad kolejnej porcji placka obserwuję sposób porozumiewa- 


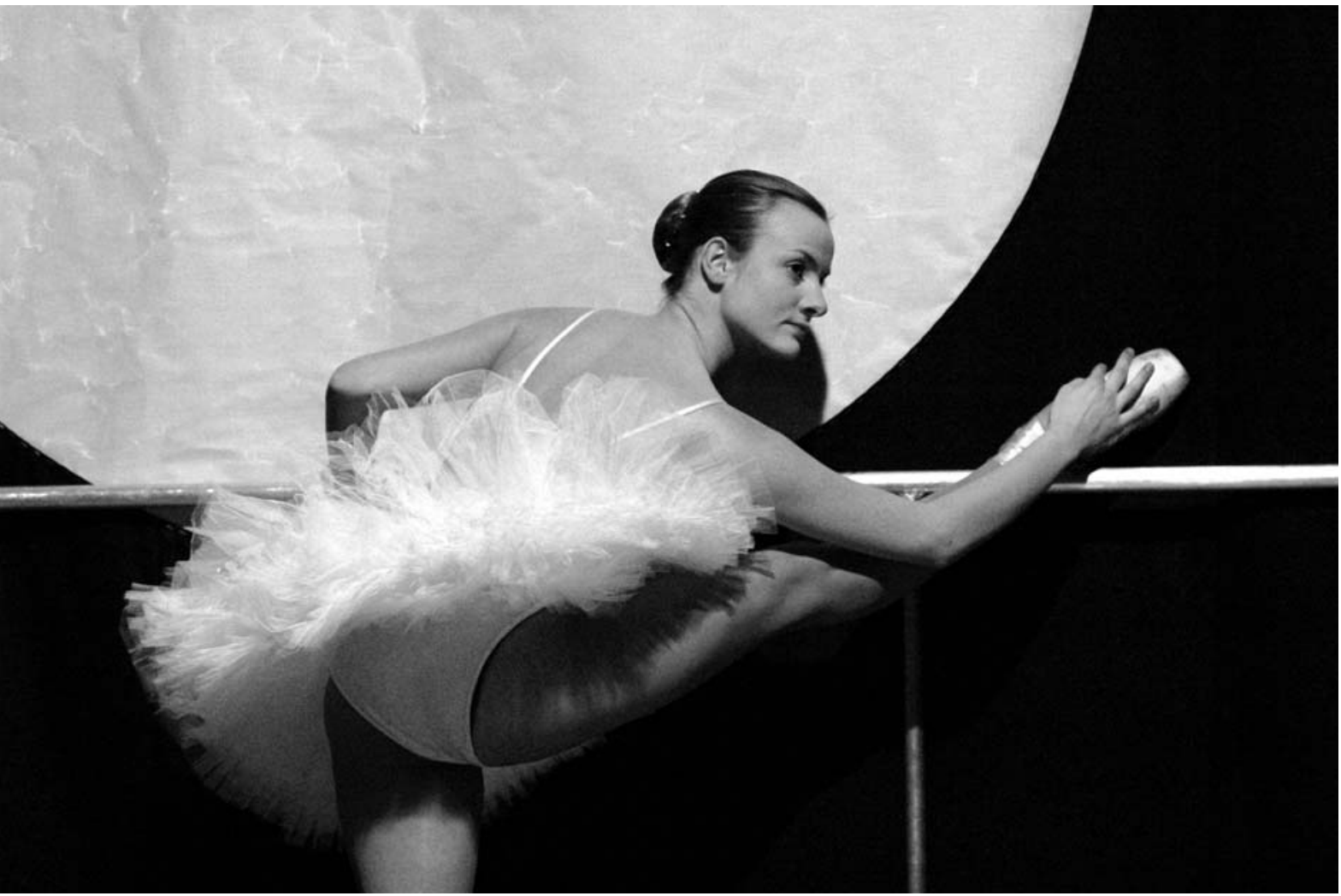

foto Tomasz Strabel

nia Karoliny z braćmi i z mamą. Nikt nie zna języka migowego, którym posługuje się Karolina. Nawet w rodzinnym domu Karoliny istnieją dwa światy. Jaka głośna to musi być samotność. Na ścianach fotografie z przedstawienia z Karoliną w białej paczce na scenie. Mama dumna z córki, ale i ona nie wierzy, że będzie miała córkę baletnicę. Raczej - cukiernika.

Dla głuchoniemych „przyszłość” to pojęcie abstrakcyjne. A - jak mówi wychowawca Karoliny - pojęć nie rozumieją... Przynajmniej nie w takich kategoriach jak my. Być może dlatego najczęściej nie mają też ambicji. Są najmniej wykształconą grupą naszego społeczeństwa. Dla większości z nich liczy się tylko tu i teraz.

Nauczycielka języka migowego w szkole, do której chodzi Karolina, ma kłopoty, żeby wytłumaczyć dzieciom, co to są na przykład anioły. Sama ma z tym kłopot, bo i ona jest niesłysząca. Albo tytuł spektaklu Narodziny świata.
Świat - globus - to jeszcze można w miarę łatwo pokazać, narodziny - dziecko, kołysanie to jeszcze też. Ale narodziny świata?!

Karolina, która w październiku ma zatańczyć w spektaklu Anioły, ma podwójnie trudne zadanie. Nie dość, że tańczy w rytm muzyki, której nie słyszy, to jeszcze tańcem opowiada historię, której nie rozumie. Ale widzowie o tym nie wiedzą. Jej talent sprawia, ze nie widać barier pomiędzy naszymi światami. Dla nich - jej taniec to sztuka. Dla niej - matematyka.

Dwa pas w przód. Obserwuję Karolinę na próbach. Kiedy płynie przez salę w rytm śpiewnego lamentu o losie Amalii Rodrigues, nie mogę wyjść z podziwu. Demi-plié revelé. Gdybym nie wiedziała, że nie słyszy, i ja nigdy bym tego nie zauważyła. Piruet. Co więcejkiedy jej słyszące koleżanki gubią rytm, ona zawsze jest na czas. Trzy pas do tyłu. Mówi się często, że głusi potrafią tańczyć, bo czują wi- 
bracje idące od głośników. Nauczycielka Karoliny temu zaprzecza. Żeby to sprawdzić, wieszała głośniki nad ziemią. Bez zmian. Jej zdaniem Karolina, jak i wielu niesłyszących ma fenomenalnie rozwiniętą pamięć. Relevé. Wszystkie kroki na pamięć. I to spojrzenie, w którym odbija się tylko cisza.

Wychowawca Karoliny także by chciał, żeby została zawodową tancerką. Ale jest bardziej sceptyczny niż jej nauczycielka tańca. Jak mówi : „Zbyt wielu moich bardzo zdolnych uczniów dzisiaj kapsluje oranżadę", a o Karolinie: „Podobno raz na pięć tysięcy lat duży meteoryt uderza w ziemię. Może więc i Karolina zostanie baletnicą..."

Na drugim biegunie tego świata jest Katarzyna i Agnieszka. Dwie siostry, które - mimo że prawie nic nie słyszą - nauczyły się czytać z ust i mówić. Chociaż obie siostry znają języki (sic!), rozmawiają przez telefony komórkowe i dobrze radzą sobie w życiu, nadal należą do tego innego świata. One same tak o tym mówią.

Kasię, atrakcyjną trzydziestoośmiolatkę, często pytają, z jakiego kraju pochodzi i jak to zrobiła, że tak świetnie zna polski. Kiedy im mówi, że po prostu jest głucha, zażenowani przepraszają, ale Kasia się z tego śmieje. Obie siostry w ogóle dużo mówią i dużo się śmieją, choć gdy się słucha, przez co przeszły, wcale nie jest do śmiechu. Ich rodzice są słyszący. O tym że Agnieszka - starsza z sióstr - nie słyszy, dowiedzieli się od lekarza, gdy miała dwa latka: „ $Z$ tego dziecka nie będzie pani miała pociechy. To przecież jest głuchy matoł".

Okazało się, że druga dziewczynka także nie słyszy. Straciła słuch prawdopodobnie po niemowlęcym zapaleniu nerek, gdy brała zbyt dużo antybiotyków. Dla rodziców to była tragedia. Przeszli przez wszelkiego rodzaju upokorzenia, bunt, rozpacz. Ale nie przestali walczyć, żeby dzieci miały w miarę normalne dzieciństwo. W efekcie Agnieszka była pierwszym dzieckiem w Poznaniu, które przyjęto do normalnej szkoły podstawowej. Na długo przed ,integracyjnym szkolnictwem” obie siostry zdały maturę w publicznych szkołach.
Agnieszka została protetykiem, a Kasia skończyła Wyższą Szkołę Plastyczną - projektowanie ubiorów.

Dziś Kasia prowadzi własną firmę aparatów słuchowych, w której pracuje też Agnieszka. Kasia zaprojektowała kolorowe wkładki do uszu. Zamiast wstydliwie ukrywać, eksponuje się je jak fantazyjną biżuterię. Agnieszka nie założyła jeszcze rodziny. Kasia jest mamą 9 letniego chłopca. Mimo że także jej partner, stomatolog, jest niesłyszący, Michaś słyszy. Co więcej, gra na pianinie, chodzi do szkoły muzycznej. Choć Kasia do dziś pamięta swój strach, gdy zasypiała bez aparatu słuchowego. Co będzie, jeśli się Michaś obudzi, a ona usłyszy jego płaczu?

Kasia ma zaprojektować i uszyć kostiumy na przedstawienie baletowe, Inny Świat, które w tym roku Anna przygotowuje wraz z grupą dzieci słyszących i niesłyszących. Ten spektakl, przygotowania i próby to główna oś filmu. To także okazja do pokazania relacji Karoliny ze światem słyszących a jednocześnie kontrast dla jej codzienności. Na próbach i w spektaklu wchodzi w swój zaczarowany świat, w którym potrafi mówić i może słyszeć. Jest częścią tego świata, którego jedynym językiem jest gest $i$ taniec. W tańcu, jak nikt inny, Karolina potrafi wytańczyć ciszę.

Kasia i Karolina spotykają się przy okazji kolejnych przymiarek. Jakkolwiek obie nie słyszą, potrzebują tłumacza, żeby się porozumieć! Stąd refleksja o granicy tego świata, którą jest język mówiony.

W filmie pokazane są też inne osoby głuchonieme - grupa jej najbliższych koleżanek i kolegów z internatu. Podpatrujemy sytuacje z ich życia: zawody ping-ponga, w którym Karolina i jej koledzy są mistrzami Polski, pokazy magii, w której się specjalizują, dyskoteki, lekcje, pisanie SMS-ów, których wynalezienie było chyba największym dobrodziejstwem właśnie dla niesłyszących. Dzięki nim komunikacja z własnym, ale także tym innym światem staje się łatwa jak nigdy. Odwiedzamy Karolinę w szkole, w której uczy się zawodu cukiernika i w domu rodzinnym. Każda scena odkrywa, 
tłumaczy widzowi jakąś cząstkę tej innej rzeczywistości. Na przykład scena, w której Karolina kłóci się z kimś. Wystarczy zamknąć oczy albo odwrócić głowę - i już kłótnia przerwana.

Razem z Karoliną idziemy na próbę Polskiego Teatru Tańca, podczas której Karolina spotka się z jego dyrektorem - Ewą Wycichowską. I przed nią zatańczy... Czy w efekcie dostanie propozycję przyszłej pracy? Czy poprzez taniec będzie miała szansę wejścia do tego innego, lepszego (?) świata.

Postacią łączącą oba światy jest nauczycielka Karoliny, Ania, śliczna, o dużym temperamencie i niespożytej energii. Wbrew temu, co sama mówi, stanowi przeciwwagę dla powiedzenia „głupia jak baletnica”. Od kilkunastu lat jako jedyna w Polsce prowadzi zajęcia baletowe między innymi z głuchoniemymi, wiele więc może o nich powiedzieć i nie boi się obnażać też przykrej prawdy. Między innymi o tym, iż żyją w przekonaniu, że wszystko się im należy, że są mało ambitni i leniwi, że szybko się zniechęcają, itp. Tym większy kontrast stanowi tutaj rodzina Kasi.
Ania zna zaledwie kilka słów w języku migowym, ale bez trudu komunikuje się z dziećmi. Jak mówi: „ja ich uczę tańca, a one uczą mnie swego języka”. Przesuwa palcami jakby szybko rozwijała wachlarz - to znaczy ładnie. Tak dzisiaj tańczyły dziewczyny. Patrzę na Karolinę - stanęła na swoich bladoróżowych pointach z rękami wzniesionymi ku górze. Ani drgnie. Jakby czas się zatrzymał...

\section{Pointa}

Karolina skończyła szkołę zawodową, zdobyła zawód cukiernika. Nie została baletnicą Polskiego Teatru Tańca, ale zdała egzaminy i przyjęto ją do baletu poznańskiego Teatru Muzycznego. Niestety, długo się w nim nie utrzymała. Zabrakło jej wytrwałości? Motywacji? Wróciła do rodzinnej wioski, wyszła za mąż za bardzo przystojnego kolegę ze szkoły. $\mathrm{Na}$ ślub zaprosiła swojego wychowawcę i nauczycielkę baletu. Podobno jest szczęśliwa. A ja piszę o niej scenariusz. Będzie się nazywał Historia bez pointy.

\title{
Images performed by words in Howard Jacobson'n novel Kalooki Nights. Remarks about intersemiotic relations among words and pictures
}

\author{
MAREK KAŹMIERCZAK
}

\section{Introduction}

The wor $(1) \mathrm{d}$ is not a picture, not an image, not even the meanings. This statement is provocative from semiotic and communicational perspective. Michel Foucault's interpretation of tension between word and picture revealed that the difference between both of these forms of creating messages are rather fluent ${ }^{1}{ }^{1}$. Howard Jacobson's[2] novel Kalooki's Nights shows that words can function as the pictures, images, like representations before meanings.

This article concerns the question created by the narrator of Howard Jacobson's novel titled Kalooki Nights. These questions are not the most important parts or frames of this novel. They are rather the margins of this text. There are many diverse issues and topics

[1] M. Foucault, To nie jest fajka (Ceci n'est pas une pipe), trans. T. Komendant, Gdańsk 1996.

[2] Howard Jacobson is a British author and journalist. He wrote i.a. Kalooki Nights (2006, Polish edition 2008), The Mighty Walzer (1999), Who's Sorry Now (2002), The Making of Henry (2004), The Act of Love (2008). 